\title{
Selective Logging Detection in the Brazilian Amazon
}

\author{
Olívia Bueno da $\operatorname{Costa}^{1}$ (D), Eraldo Aparecido Trondoli Matricardi ${ }^{1}$ (D), \\ Marcos Antonio Pedlowski² (D), Eder Pereira Miguel ${ }^{1}$ (D), \\ Ricardo de Oliveira Gaspar ${ }^{1}$ \\ ${ }^{1}$ Universidade de Brasilia - UNB, Brasília/DF, Brasil \\ ${ }^{2}$ Universidade Estadual do Norte Fluminense - UENF, Campos dos Goytacazes/RJ, Brasil
}

\begin{abstract}
Selective logging activities are commonly observed in the Brazilian Amazon and are responsible for high forest impact. In this study, selective logging detection techniques and the spatiotemporal extension of forests impacted by logging activities between 2003 and 2014 in portions of the states of Mato Grosso, Pará, and Rondônia were assessed using remotely sensing data. Based on results obtained, it was estimated that the overall accuracies are greater than $91 \%$ for techniques applied to detect forests impacted by selective logging in the study areas. Forests impacted by selective logging increased in Western state of Mato Grosso and Northern state of Rondônia, which indicates a stage high forest activity in these regions. In contrast, in Eastern state of Pará, a decrease in forests impacted by logging activities was observed, which indicates collapsed stage of logging activities resulting from deforestation and predatory logging in that region.
\end{abstract}

Keywords: Legal Amazon, geoprocessing and forest degradation. 


\section{INTRODUCTION}

Forest degradation in the Amazon has several consequences to ecological processes (Koltunov et al., 2009; Andrade et al., 2014; Berenguer et al., 2014). Canopy openings left by selective logging activities combined with large amounts of organic matter from dead trees increases forest vulnerability to subsequent fires (Uhl \& Kauffman, 1990; Holdsworth \& Uhl, 1997; Nepstad et al., 1998; Fearnside, 1999; Cochrane \& Laurance, 2008).

Conventional selective logging results in greater impacts on forests as it removes timber species usually without proper planning and/or logging techniques. In contrast, selective logging uses several techniques that reduce forest damage and shorten the forest recovery period based on the detailed planning of logging activities (Putz et al., 2012; West et al., 2014).

Forest degradation as a result of selective logging activities, especially by conventional logging, causes the release of substantial amounts of carbon into the atmosphere (Huang \& Asner, 2010; Berenguer et al., 2014). In the period between 2007 and 2013, selective logging activities and forest fires accounted for $47 \%$ (gross average of emissions) of deforestation that took place in the same period in the Amazon (Aguiar et al., 2016).

The detection of high-intensity selective logging in Amazon forests is fundamental for the analysis and the understanding of the spatial distribution of forest degradation, and to support the study of current climate changes and deforestation. Based on the above, remotely sensing imagery is a crucial data source for mapping selective logging in dense and inaccessible
Amazon areas, since it allows a broad view and quick coverage of the area of interest (Souza et al., 2005; Anwar \& Stein, 2012) at low cost (Nepstad et al., 1999).

Different mapping techniques to detect forests degraded by selective logging activities in the Legal Amazon are described in literature, such as visual interpretation, spectral mixture analysis, texture filter, CLASlite, as well as radar and Lidar detectors (Asner et al., 2005; Matricardi et al., 2010; Keller et al., 2012; Souza et al., 2013; Andersen et al., 2014; Joshi et al., 2015; INPE, 2016). However, such studies have focused on the temporal assessment or spatial dimension of forest degradation.

The aim of this study was to assess the accuracy of selective logging detection techniques used in the Amazon, especially in areas of forests submitted to legal and illegal conventional selective logging. This study also sought to estimate areas of selectively logged forests in sites spatially located in the states of Mato Grosso, Pará, and Rondônia. These results can be used for developing and applying remote sensing techniques to assess forest impacts in the Amazon.

\section{METHODS}

The study sites comprised three states of the Brazilian Legal Amazon: Mato Grosso (municipalities of Santa Carmen, Nova Ubiratã, and Feliz Natal), Pará (municipalities of Paragominas, Goianésia do Pará, Dom Eliseu, and Ulianópolis) and Rondônia (municipality of Porto Velho), spatially located within five Landsat 5 (TM) and Landsat 8 (OLI) scenes (Figure 1) (Table 1).

Landsat scenes were radiometrically corrected for physical values at the Top Of the Atmosphere (TOA)

Table 1. Landsat and Rapid Eye images acquired in 2014 used to assess the accuracy of the selective logging classification.

\begin{tabular}{|c|c|c|c|c|c|c|}
\hline \multirow{2}{*}{ Satellite/Sensor } & \multicolumn{2}{|c|}{ Mato Grosso } & \multicolumn{2}{|c|}{ Pará } & \multicolumn{2}{|c|}{ Rondônia } \\
\hline & Scene & Date & Scene & Date & Scene & Date \\
\hline \multirow{2}{*}{$\begin{array}{c}\text { Landsat } \\
\text { (OLI) }\end{array}$} & $226 / 68$ & Oct 23 & $223 / 62$ & Dec 21 & $232 / 66$ & Oct 1 \\
\hline & $226 / 69$ & Aug 20 & $223 / 63$ & $\operatorname{Dec} 21$ & & \\
\hline \multirow{6}{*}{ RapidEye } & 2133426 & May 6 & 2237328 & June 26 & 2035216 & June 24 \\
\hline & 2133527 & May 6 & 2237427 & June 26 & 2035215 & June 24 \\
\hline & 2133427 & July 5 & 2237428 & June 26 & & \\
\hline & 2133526 & July 5 & 2237327 & June 26 & & \\
\hline & 2133525 & May 1 & & & & \\
\hline & 2133425 & Aug 13 & & & & \\
\hline
\end{tabular}




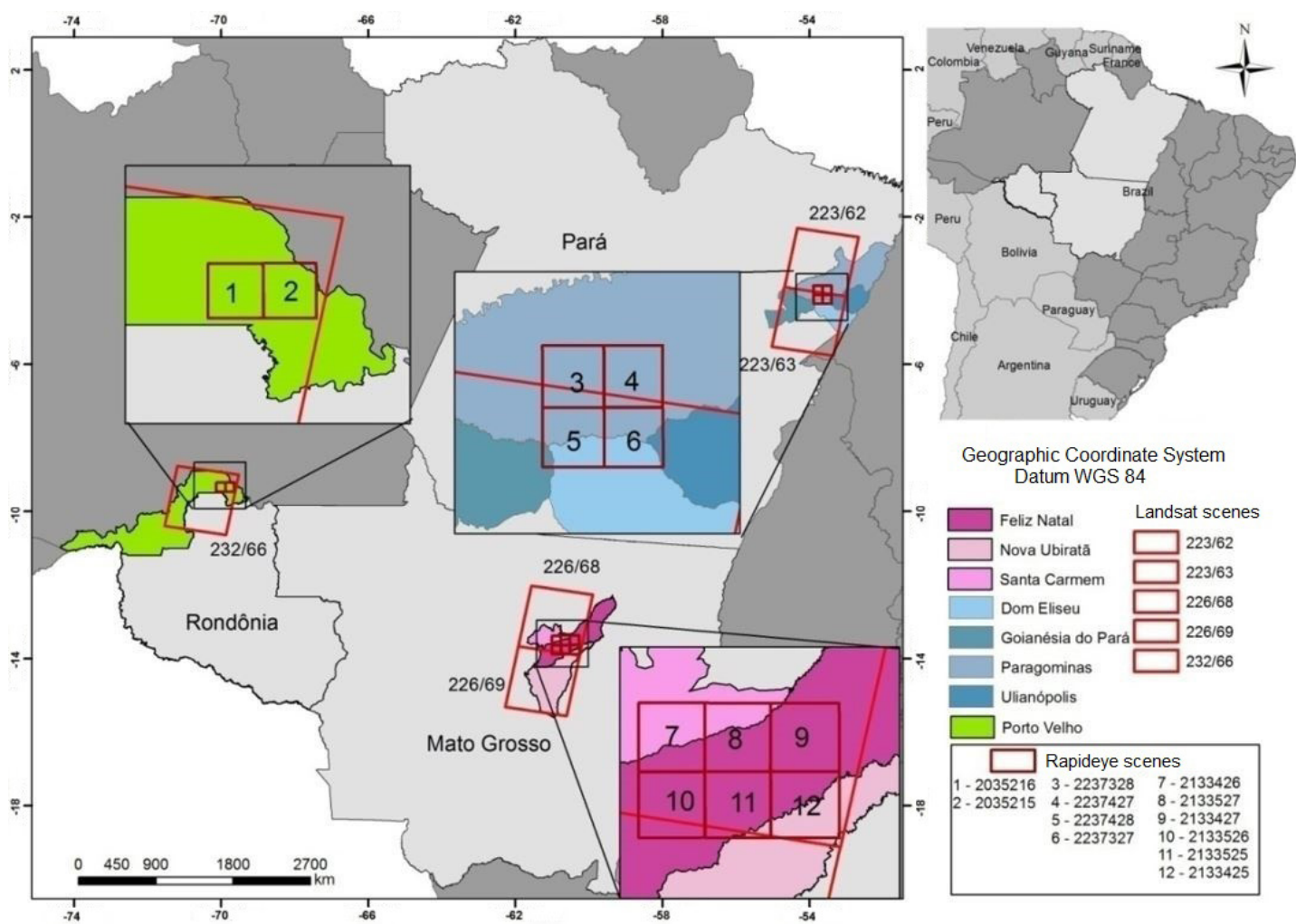

Figure 1. Study area and Landsat and Rapid Eye images used to assess the accuracy of the selective logging mapping technique.

reflectance (Chander et al., 2009) using ENVI ${ }^{\circledR}$ 5.0. Subsequently, Landsat scenes were georeferenced using Datum WGS 84 Datum and UTM projection system. Image georeferencing was conducted using six control points from an orthorectified image (acquired from the US Geological Survey - USGS) and images acquired from the INPE (Institute of Space Research) website. The six control points were used for image rectification by applying the first-order polynomial and nearest neighbor re-sampling technique. Individual image geometric correction was only accepted if $R M S$ value was lower than 0.5 pixels (Dewa \& Danoedoro, 2017).

The methodology (Figure 2) was based on applying a semiautomatic technique that combined texture algorithm for detecting log-landing patios and eye-inspection to map selectively logged forests, showing obvious forest degradation through Landsat-5 TMimages (acquired in 2003, 2006, and 2010) and Landsat-8 OLI images (acquired in 2014). Forest and non-forest mask was created from PRODES (Monitoring of the Brazilian Amazonian Forest by Satellite) deforestation dataset to mask out "deforestation" lands, since this study was focused on forested areas only. A buffer zone of $180 \mathrm{~m}$ corresponding to area impacted by selective logging activities was built around detected log-landing patios. This buffer zone was defined based on field measurements conducted by Matricardi et al. (2010) and applied in this study (Figure 2).

Confusion matrix was used to estimate the overall accuracy, commission and omission errors, producer and user accuracies of the selective logging mapping technique applied on five Landsat images acquired in 2014 (Congalton \& Green, 2008).

The classification conducted on the Landsat imagery was eye-inspected on a computer screen using twelve high spatial resolution ( $5 \mathrm{~m}$ ) Rapid Eye satellite images. Additional observations related to the spectral patterns of selective logging on satellite images were carried out during fieldwork conducted in November 2016 in the states of Mato Grosso (municipality of Feliz Natal) and Rondônia (municipality of Porto Velho).

Six Rapid Eye satellite images were used for the study site in the state of Mato Grosso (Figure 1, Table 1). A polygon including the six Rapid Eye images was built 


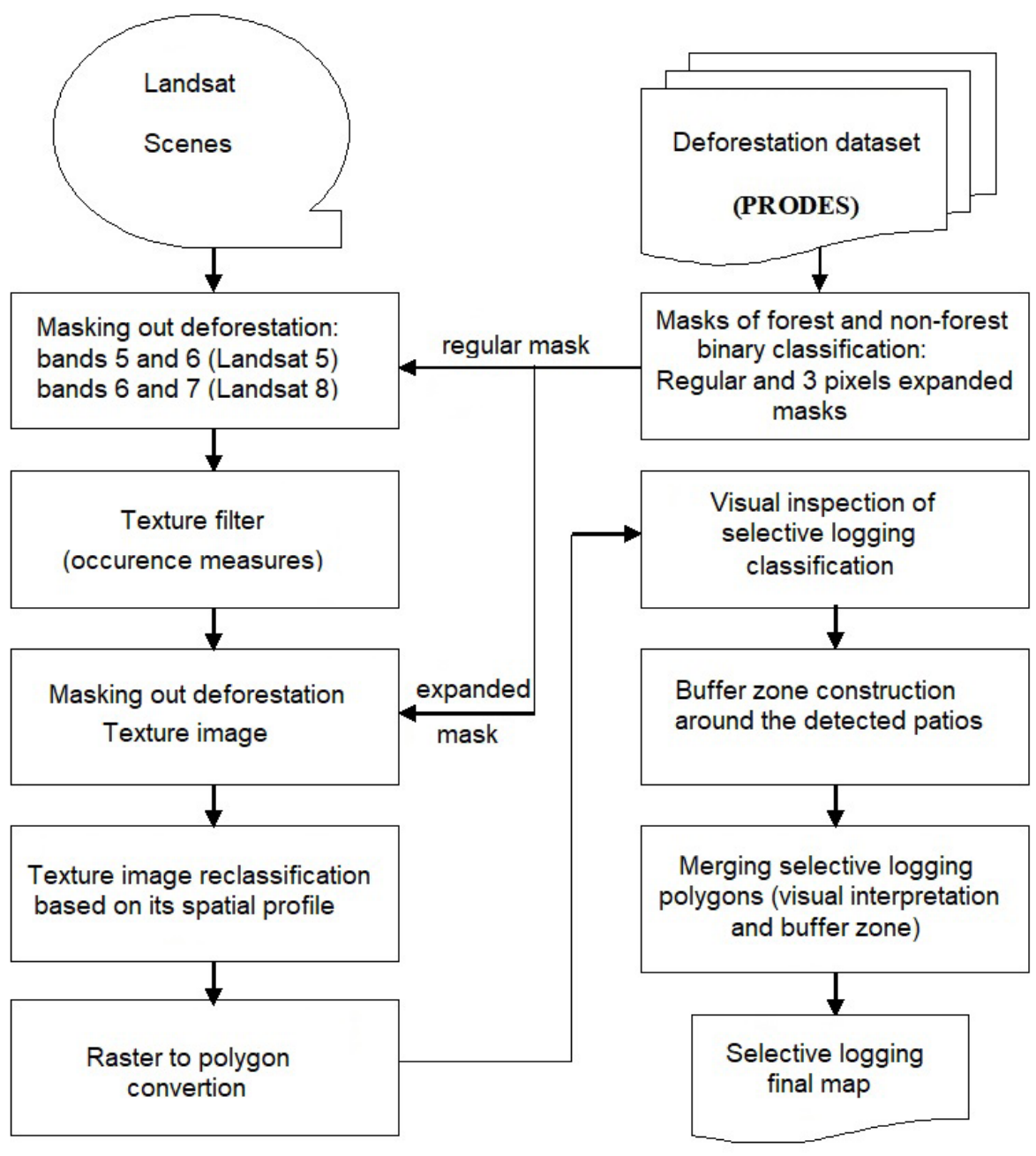

Figure 2. Flow diagram for the selective semi-automated logging detection technique using Landsat Imagery.

and 260 points were randomly distributed within the polygon adopting minimum distance of 500 meters from each other. This procedure ensured that the random sampling points were more efficiently distributed throughout the study area. Dates the closest as possible between Landsat-8 and Rapid Eye images were searched to reduce seasonal effects on satellite images.

Finally, points randomly sampled distributed over the study site were used to observe evidence of selective logging on Rapid Eye images. Based on visual evidences of selective logging observed on Rapid Eye images, each sampled point was classified either as selectively logged forest or not logged forest and compared to classification based on two Landsat 8 images (Path/Row226/68 and 226/69) in the state of Mato Grosso.
Four Rapid Eye images were used (Figure 1, Table 1) in the state of Pará. The previously described methodological procedures were adopted to assess selective logging classification accuracy in Pará. A total of 200 sample points were randomly distributed within Rapid Eye images and compared to classification based on Landsat 8 images 223/62 and 223/63.

Similarly, two Rapid Eye images were used (Figure 1, Table 1) in the state of Rondônia. A total of 100 sample points were randomly distributed within these images and compared the selective logging classification based on Landsat-8 image 232/66.

Finally, Kappa coefficient (Equation 1) (Cohen, 1960) and confusion matrixes were estimated for Mato Grosso, Pará, and Rondônia: 


$$
k=\frac{N \sum_{i=1}^{r} x i i-\sum_{i=1}^{r}\left(x_{i+} * x_{+i}\right)}{N^{2}-\sum_{i=1}^{r}\left(x_{i+} * x_{+i}\right)}
$$

where: $\mathrm{k}=$ Kappa coefficient; $\mathrm{N}=$ total number of sampled points; $r=$ number of rows in the error matrix; $\mathrm{x}_{\mathrm{ii}}=$ value of row $\mathrm{i}$ and column $\mathrm{i} ; \mathrm{x}_{+\mathrm{i}}=$ total value of column $i ; x_{i+}=$ total value of row $i$.

\section{RESULTS AND DISCUSSION}

\subsection{Accuracy analysis}

Our results indicate a good accuracy for the selective logging classification technique. Overall, 91\%, 93\%, and $93 \%$ of accuracy classification were estimated for the states of Mato Grosso, Pará, and Rondônia, respectively. These accuracy results are above the $85 \%$ minimum threshold used as reference for good accuracy classification (Pringle et al., 2009). Therefore, our results indicated good agreement between selective logging classification and visual observations on the Rapid Eye images and field.

More specifically, $12 \%$ of sampled points were omitted and $9.4 \%$ of sampled points were commissioned for selectively logged forests. These results indicated that
$88.1 \%$ of sampled points observed as selective logging were correctly classified by the applied classification technique (Table 2). The Kappa coefficient presented value of $82 \%$ for the technique, with good agreement between the image taken as field truth and the selective exploration classification (Congalton \& Green, 2008).

For the state of Pará, it was estimated that $7.4 \%$ of selectively logged forests were omitted and $7.4 \%$ were committed by the applied classification technique. Based on underestimation (omitted) and overestimation (committed) errors, $92.6 \%$ of selectively logged forests were correctly detected and classified (Table 3 ). Kappa coefficient showed accuracy of $82 \%$, which is considered good agreement between selective logging observed on the reference Rapid Eye images and field and the Landsat image classification (Congalton \& Green, 2008).

Sources of omission and commission errors are mainly caused by the spatial resolution (30m) of Landsat imagery used in this study. Each image pixel using this spatial resolution encompasses $900 \mathrm{~m}^{2}$ in the ground, which leads to spectral mixtures by ground features. These spectral mixtures may increase errors of the automatic classification, leading to misclassifications by applying automatic algorithms and visual interpretation. Altogether, it may reduce classification accuracy.

Table 2. Accuracy of the selective logging detection technique in the study area spatially located in the state of Mato Grosso in 2014.

\begin{tabular}{|c|c|c|c|c|c|c|}
\hline & \multirow[b]{2}{*}{ Usage Classes } & \multicolumn{3}{|c|}{ Rapid Eye image } & \multirow{2}{*}{$\begin{array}{l}\text { Producer } \\
\text { Accuracy }\end{array}$} & \multirow{2}{*}{$\begin{array}{c}\text { User } \\
\text { Accuracy }\end{array}$} \\
\hline & & $\begin{array}{c}\text { Selective } \\
\text { logging }\end{array}$ & Other uses & Total & & \\
\hline \multirow{3}{*}{ Classified image } & Selective logging & 96 & 10 & 106 & $88.1 \%$ & $91 \%$ \\
\hline & Other uses & 13 & 141 & 154 & $93 \%$ & $92 \%$ \\
\hline & Total & 109 & 151 & 260 & & \\
\hline Omission errors & & $11.9 \%$ & $7 \%$ & & & \\
\hline Commission errors & & $9.4 \%$ & $8.4 \%$ & & & \\
\hline Overall accuracy & & $91 \%$ & & & & \\
\hline
\end{tabular}

Table 3. Accuracy of the selective logging classification technique in the study area spatially located in the state of Pará in 2014.

\begin{tabular}{|c|c|c|c|c|c|c|}
\hline & \multirow[b]{2}{*}{ Usage Classes } & \multicolumn{3}{|c|}{ Rapid Eye image } & \multirow{2}{*}{$\begin{array}{l}\text { Producer } \\
\text { Accuracy }\end{array}$} & \multirow{2}{*}{$\begin{array}{c}\text { User } \\
\text { Accuracy }\end{array}$} \\
\hline & & $\begin{array}{l}\text { Selective } \\
\text { logging }\end{array}$ & Other uses & Total & & \\
\hline \multirow{3}{*}{ Classified image } & Selective logging & 87 & 7 & 94 & $92.6 \%$ & $92.6 \%$ \\
\hline & Other uses & 7 & 99 & 106 & $93 \%$ & $93 \%$ \\
\hline & Total & 94 & 106 & 200 & & \\
\hline Omission errors & & $7.4 \%$ & $7 \%$ & & & \\
\hline Commission errors & & $7.4 \%$ & $7 \%$ & & & \\
\hline Overall accuracy & & $93 \%$ & & & & \\
\hline
\end{tabular}


Another factor affecting classification accuracy is the adjustment of maximum and minimum values of the spatial profile of texture images when applying semiautomatic classification to detect log-landing patios. These values are empirically adjusted based on the spectral response of ground features that represent log-landing patios and may lead to misclassification. Intended omission of subtle and more isolated log-landing patios may occur to avoid potential overestimation errors.

Another source of classification errors is related to the acquisition date of Rapid Eye and Landsat imagery used in each study site. Seasonal variation is crucial in the Amazon region and may abruptly change vegetation spectral responses during dry and wet seasons. In addition, remotely sensing images are not always available for specific dates, which is a challenge for comparison of image classifications. Some forested areas classified as selectively logged may be detected on a specific satellite image and may be missing in another image acquired one month earlier or later due to the seasonal variation effect.

Classification accuracy also may be affected by data transformation from continuous field, such as multispectral images, to categorical image (classified), in which class boundaries are defined. Although several surface targets show well-defined borders or edges, there are many cases showing smooth transition edges. Features showing smooth transition edges are commonly affected by categorical classifications, which ultimately affect classification accuracy (Gopal \& Woodcock, 1994), as is the case of selectively logged forests in the Amazon region.

Finally, it was observed that 59 of the 100 sampled points within the state of Rondônia were classified as selectively logged forests. Only 1 of the 59 sampled points was incorrectly classified as other land uses, which resulted in omission error of $2 \%$ (Table 4). Six sampled points were incorrectly classified as "other uses", which resulted in commission error of $9.4 \%$. The selective logging accuracy was $98 \%$ and Kappa coefficient was $85.3 \%$, which indicate very good classification performance.

\subsection{Selective logging classification}

Our results showed an increase of selective logging and deforestation in the state of Mato Grosso during the period of analysis (Figures $3 \mathrm{~A}$ and $4 \mathrm{~A}$ ) (Table 5). This increase occurred mostly within Landsat image $226 / 68$. Despite the increase in forests impacted by logging activities, a decrease in anthropogenic activities in the coming years in the study sites is expected. This is mostly like due to the old colonization frontier characteristics in eastern Mato Grosso where high-intensity selective logging ("logging boom") activities are commonly followed by timber exhaustion or collapse of native forests (Keller et al., 2002; Veríssimo \& Cochrane, 2003; Weinhold et al., 2015).

Reduction of selective logging areas and increase of deforestation areas were observed during the period of analysis (Figures 3B and 4B) in the state of Pará. This result is due to the overexploitation of native forests and deforestation, where the boom logging period was over and the area is currently facing the "bust" period, predominantly occupied by deforested lands and, as result, selective logging activities are moved to other areas (Schneider et al., 2002; Weinhold et al., 2015). In the area in the state of Rondônia, an increase in the selective logging area during the study period was observed (Figure 3C).

Table 4. Accuracy of the selective logging detection technique in the study site spatially located in the state of Rondônia in 2014.

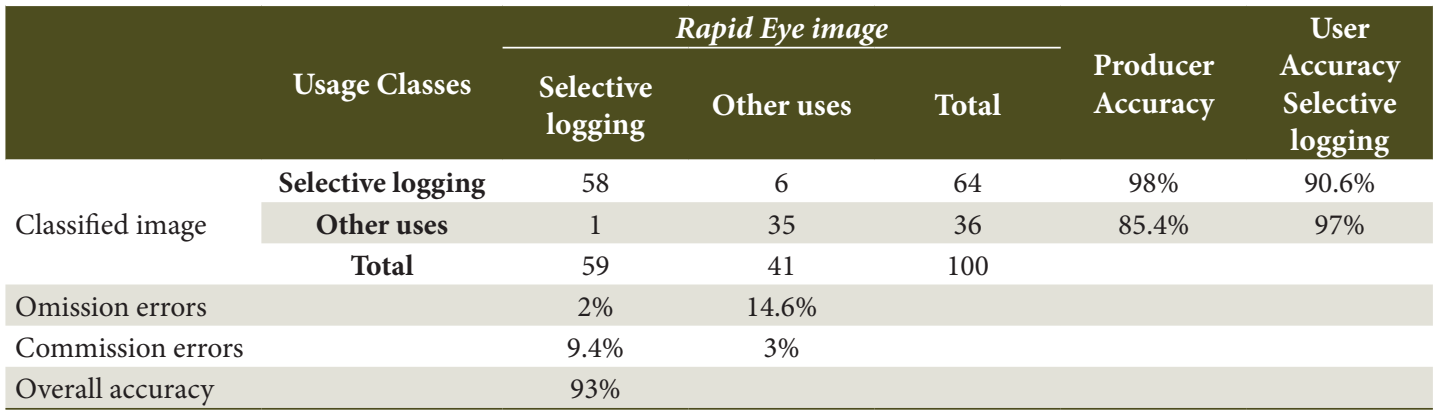



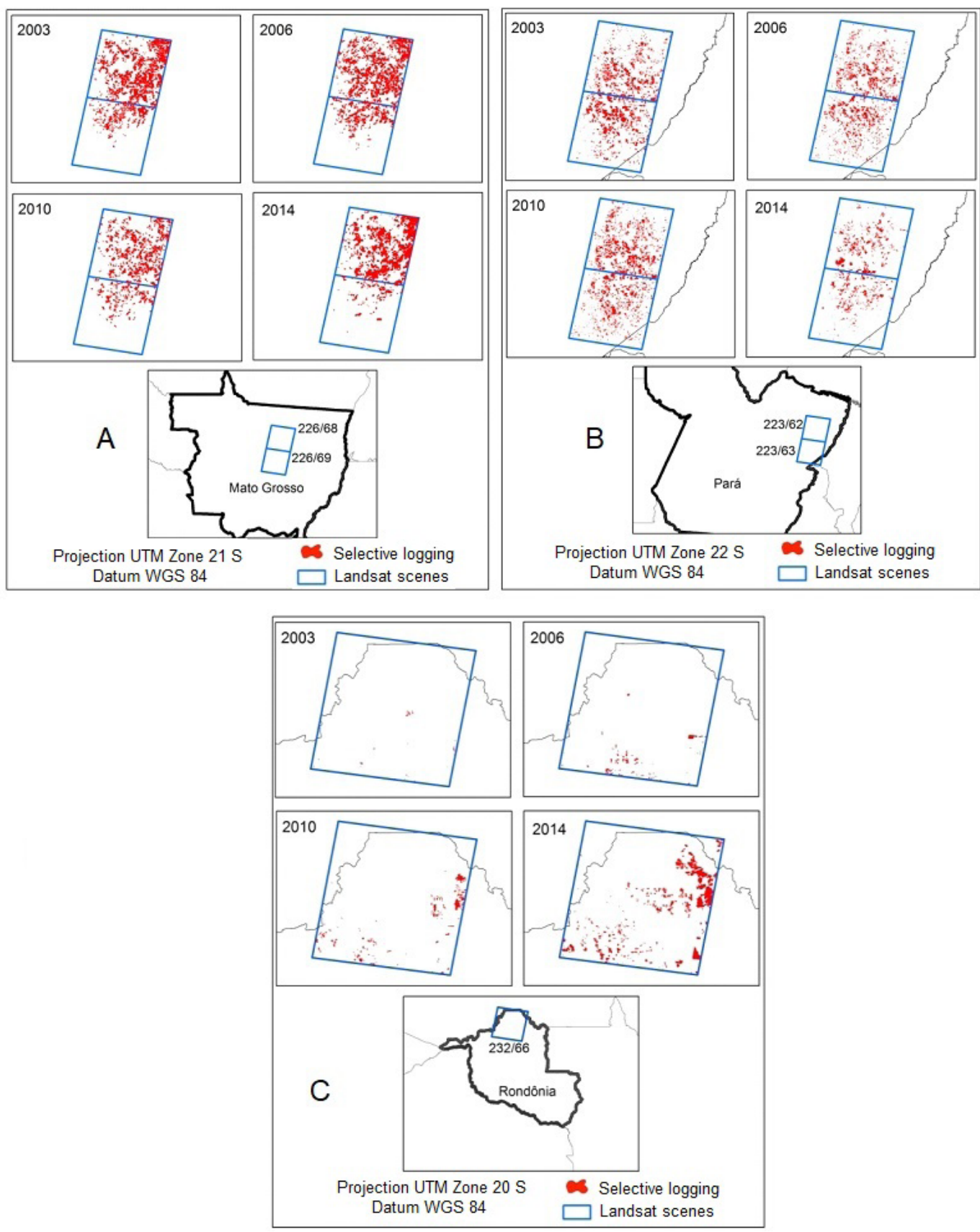

Figure 3. Selective logging area detected within the study areas in the states of Mato Grosso (A), Pará (B), and Rondônia (C) in 2003, 2006, 2010, and 2014.

Table 5. Selective logging area for Landsat images between 2003 and 2014.

\begin{tabular}{|c|c|c|c|c|c|}
\hline \multirow{2}{*}{ State } & \multirow{2}{*}{ Landsat Images } & \multicolumn{4}{|c|}{ Year } \\
\hline & & 2003 & 2006 & 2010 & 2014 \\
\hline \multirow{2}{*}{ Mato Grosso } & $226 / 68$ & $4,900.60$ & $5,191.70$ & $3,508.10$ & $6,180.40$ \\
\hline & $226 / 69$ & $1,220.40$ & $1,394.50$ & $1,067.20$ & 613.4 \\
\hline \multirow{2}{*}{ Pará } & $223 / 62$ & $4,030.20$ & $3,660.00$ & $4,868.10$ & $2,354.10$ \\
\hline & $223 / 63$ & $4,308.60$ & $3,208.80$ & $3,500.80$ & $1,623.90$ \\
\hline Rondônia & $232 / 66$ & 43.5 & 209.4 & 470 & $1,745.10$ \\
\hline
\end{tabular}



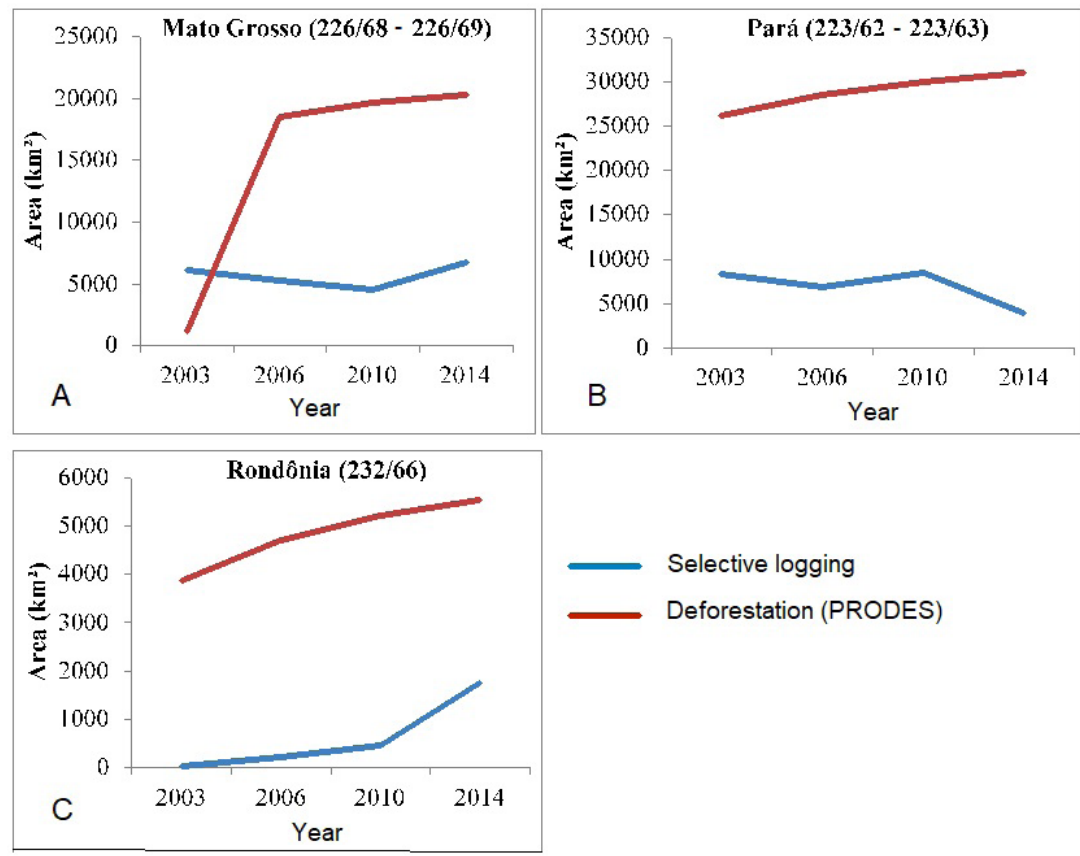

Figure 4. Selectively logged and deforested areas within the studied sites in the states of Mato Grosso (A), Pará (B) and Rondônia (C) in 2003, 2006, 2010, and 2014.

In the study area in Rondônia, an increase in the selective logging area was observed (Figure 4C), which determined a new selective logging frontier. This new logging frontier, spatially located in Northern Rondônia, is currently experiencing a boom logging period and it is expected to increase in the coming years.

Most processes of forest degradation by selective logging in the Amazon follow the same spatial patterns observed in this study: high commercial value tree species are removed damaging several other trees during the removal process. Selective logging activities remain until most of valuable timber species disappear and land has more value with agriculture or pasture than with forest itself. Ultimately, economically impoverished forests will lead to forest conversion into agricultural fields or pasture lands (Gerwing et al., 1996; Schneider et al., 2002; Asner et al., 2006).

Meanwhile, depletion of timber resources in some regions (Eastern Pará, Mid-Northern Mato Grosso and Southeastern Rondônia) leads to an increase of agriculture-based land use in the Amazon, mainly the expansion of soybean cropping fields (Schneider et al., 2002; Veríssimo \& Cochrane, 2003; Tritsch \& Arvor, 2016; Costa et al., 2017) and pastures. Selective logging frontiers are followed by the expansion of agricultural activities. Illegal selective logging has severely degraded natural forest resources in previously known "selective logging centers". Currently, selective logging is moving towards the state of Amazonas and Western and Northern Pará, often within indigenous and protected areas (Schneider et al., 2002).

\section{CONCLUSIONS}

The selective logging detection technique that combines visual interpretation and semi-automatic technique based on texture algorithm has shown good classification performance as indicated by the overall accuracy and Kappa coefficient results. Based on results, it could be concluded that this classification technique can be extrapolated for mapping selective logging in other regions of the Brazilian Amazon.

However, image choice for classification and validation should focus on acquisition dates during dry season with higher vegetative stress. By combining vegetation stress due to water deficit and impacts by selective logging activities will enhance selectively logged forests in contrast to undisturbed ones through satellite images. Additionally, impacts by selective logging remain detectable on Landsat images from 1 to 3 years and, therefore, closer proximity image acquisition dates will favor detection techniques. 
The results of this study indicated a decrease in selective logged sites in the state of Pará, while the amount of deforested areas increased. In this case, there was a displacement of selective logging activities to new frontiers due to the lack of forests in older colonization regions due to deforestation and conventional and predatory selective logging activities.

Selective logging area in the study sites corresponds to a small portion of the three states of the Brazilian Legal Amazon. Therefore, a broader understanding of the land use dynamics, especially forest impacts, will require more spatially and temporally comprehensive studies.

\section{ACKNOWLEDGEMENTS}

This work was supported by the Graduate Program in Forest Science of UnB. We would like to thank the anonymous reviewers of the FLORAM Journal for helping to improve the scientific quality of this article.

\section{SUBMISSION STATUS}

Received: 18 aug., 2017

Accepted: 08 nov., 2017

\section{CORRESPONDENCE TO}

\section{Eraldo Aparecido Trondoli Matricardi}

Faculdade de Tecnologia, Universidade de Brasília - UnB, Campus Darcy Ribeiro, Asa Norte, CEP 70910-900, Brasília, DF, Brasil e-mail: ematricardi@gmail.com

\section{FINANCIAL SUPPORT}

Financial support for this study was provided by Coordination for the Improvement of Higher Education Personnel (CAPES) and by the Brazilian National Council of Science and Technology (CNPQ).

\section{REFERENCES}

Aguiar APD, Vieira ICG, Assis TO, Dalla-Nora E, Toledo PM, Santos-Júnior RAO et al. Land use change emission scenarios: anticipating a forest transition process in the Brazilian Amazon. Global Change Biology 2016; 22(5): 1821-1840. http://dx.doi.org/10.1111/gcb.13134. PMid:26511401.
Andersen H-E, Reutebuch SE, McGaughey RJ, d'Oliveira MVN, Keller M. Monitoring selective logging in western Amazonia with repeat lidar flights. Remote Sensing of Environment 2014; 151: 157-165. http://dx.doi.org/10.1016/j. rse.2013.08.049.

Andrade RB, Barlow J, Louzada J, Vaz-De-Mello FZ, Silveira JM, Cochrane CM. Tropical forest fires and biodiversity: dung beetle community and biomass responses in a northern Brazilian Amazon forest. Journal of Insect Conservation 2014; 18(6): 1097-1104. http:// dx.doi.org/10.1007/s10841-014-9719-4.

Anwar S, Stein A. Detection and spatial analysis of selective logging with geometrically corrected Landsat images. International Journal of Remote Sensing 2012; 33(24): 7820-7843. http://dx.doi.org/10.1080/0143116 1.2012.701378.

Asner GP, Broadbent EN, Oliveira PJC, Keller M, Knapp DE, Silva JNM. From the Cover: condition and fate of logged forests in the Brazilian Amazon. Proceedings of the National Academy of Sciences of the United States of America 2006; 103(34): 12947-12950. http://dx.doi. org/10.1073/pnas.0604093103. PMid:16901980.

Asner GP, Knapp DE, Broadbent EN, Oliveira PJC, Keller M, Silva JN. Selective logging in the Brazilian Amazon. Science 2005; 310(5747): 480-482. http://dx.doi.org/10.1126/ science.1118051. PMid:16239474.

Berenguer E, Ferreira J, Gardner TA, Aragão LEOC, Camargo PB, Cerri CE et al. A large-scale field assessment of carbon stocks in human-modified tropical forests. Global Change Biology 2014; 20(12): 3713-3726. http:// dx.doi.org/10.1111/gcb.12627. PMid:24865818.

Chander G, Markham BL, Helder DL. Summary of current radiometric calibration coefficients for Landsat MSS, TM, ETM+, and EO-1 ALI sensors. Remote Sensing of Environment 2009; 113(5): 893-903. http://dx.doi. org/10.1016/j.rse.2009.01.007.

Cochrane CM, Laurance WF. Synergisms among fire, land use, and climate change in the Amazon. Ambio 2008; 37(7-8): 522-527. http://dx.doi.org/10.1579/0044-744737.7.522. PMid:19205173.

Cohen J. A coefficient of agreement for nominal scales. Educational and Psychological Measurement 1960; 20(1): 37-46. http://dx.doi.org/10.1177/001316446002000104.

Congalton RG, Green K. Assessing the accuracy of remotely sensed data. 2. ed. Boca Raton: CRC Press; 2008. http:// dx.doi.org/10.1201/9781420055139.

Costa OB, Matricardi EAT, Pedlowski M, Cochrane CM, Fernandes C. Spatiotemporal mapping of soybean plantations in Rondônia, Western Brazilian Amazon. Acta Amazonica 2017; 47(1): 29-38. http://dx.doi. org/10.1590/1809-4392201601544.

Dewa RP, Danoedoro P. The effect of image radiometric correction on the accuracy of vegetation canopy density 
estimate using several Landsat-8 OLI's vegetation indices: a case study of Wonosari area, Indonesia. In: IOP Conferences Series: Earth and Environmental Science; 2017; Bogor, Indonesia. Bristol: IOP Publishing; 2017. Vol. 54. p. 1-7. https://doi.org/10.1088/1755-1315/54/1/012046.

Fearnside PM. Biodiversity as an environmental service in Brazils Amazonian forests: risks, value and conservation. Environmental Conservation 1999; 26(4): 305-321. http:// dx.doi.org/10.1017/S0376892999000429.

Gerwing J, Johns J, Vidal E. Reduncing waste during logging and log processing: forest conservation in Eastern Amazonia. UNASYLVA - FAO; 1996. p. 17-25.

Gopal S, Woodcock C. Theory and methods for accuracy assessment of thematic maps using fuzzy sets. Photogrammetric Engineering and Remote Sensing 1994; 60: 181-188.

Holdsworth AR, Uhl C. Fire in Amazonian selectively logged rain forest and the potential for fire reduction. Ecological Applications 1997; 7(2): 713-725. http://dx.doi. org/10.1890/1051-0761(1997)007[0713:FIASLR]2.0.CO;2.

Huang M, Asner GP. Long-term carbon loss and recovery following selective logging in Amazon forests. Global Biogeochemical Cycles 2010; 24(3): 1-15. http://dx.doi. org/10.1029/2009GB003727.

Instituto Nacional de Pesquisas Espaciais - INPE. Dados do desmatamento e degradação na Amazônia [online]. São José dos Campos: INPE; 2016 [cited 2016 Aug 22]. Available from: http://www.inpe.br/

Joshi N, Mitchard ETA, Woo N, Torres J, Moll-Rocek J, Ehammer A et al. Mapping dynamics of deforestation and forest degradation in tropical forests using radar satellite data. Environmental Research Letters 2015; 10(3): 1-13. http://dx.doi.org/10.1088/1748-9326/10/3/034014.

Keller M, Asner GP, Silva N, Palace M. Sustainability of selective loggin of upland forests in the Brazilian Amazon: carbon budget and remote sensing as tools for evaluation of logging effects. In: Zarin DJ, Alavalapati JRR, Putz FE, Schmink M, editor. Working forests in the tropics: conservation through sustainable management?. New York: Columbia University Press; 2002.

Keller M, Oliveira MVN, Takemura CM, Vitoria D, Araujo LS, Morton DC. Automated detection of selective logging in Amazon forests using airborne Lidar data and pattern recognition algorithms. In: Proceedings of the AGU Fall Meeting, 2012 - ALICE; 2012; San Franciso. Brasília: EMBRAPA; 2012.

Koltunov A, Ustin SL, Asner GP, Fung I. Selective logging changes forest phenology in the Brazilian Amazon: evidence from MODIS image time series analysis. Remote Sensing of Environment 2009; 113(11): 2431-2440. http://dx.doi. org/10.1016/j.rse.2009.07.005.

Matricardi EAT, Skole DL, Pedlowski MA, Chomentowski W, Fernandes LC. Assessment of tropical forest degradation by selective logging and fire using Landsat imagery. Remote Sensing of Environment 2010; 114(5): 1117-1129. http:// dx.doi.org/10.1016/j.rse.2010.01.001.

Nepstad D, Moreira A, Veríssimo A, Lefebvre P, Schlesinger $\mathrm{P}$, Potter $\mathrm{C}$ et al. Forest fire prediction and prevention in the Brazilian Amazon. Conservation Biology 1998; 12(5): 951953. http://dx.doi.org/10.1046/j.1523-1739.1998.00004.x.

Nepstad DC, Moreira AG, Alencar AA. Flames in the rain forest: origins, impacts, and alternatives to Amazonian fires. Washington: World Bank; 1999.

Pringle MJ, Schmidt M, Muir JS. Geostatistical Interpolation of SLC -off Landsat ETM+ images. ISPRS Journal of Photogrammetry and Remote Sensing 2009; 64(6): 654664. http://dx.doi.org/10.1016/j.isprsjprs.2009.06.001.

Putz FE, Zuidema PA, Synnott T, Peña-Claros M, Pinard MA, Sheil D et al. Sustaining conservation values in selectively logged tropical forests: the attained and the attainable. Conservation Letters 2012; 5(4): 296-303. http:// dx.doi.org/10.1111/j.1755-263X.2012.00242.x.

Schneider RR, Arima E, Veríssimo A, Souza CMJ, Barreto P. Sustainable Amazon: limitation and opportunities for rural development [online]. 2002 [cited 2006 Aug 31]. Available from: http://documents.worldbank.org/curated/ pt/270371468005675190/Sustainable-Amazon-limitationsand-opportunities-for-rural-development

Souza CM Jr, Roberts DA, Cochrane MA. Combining spectral and spatial information to map canopy damage from selective logging and forest fires. Remote Sensing of Environment 2005; 98(2): 329-343. http://dx.doi. org/10.1016/j.rse.2005.07.013.

Souza CM Jr, Siqueira JV, Sales MH, Fonseca AV, Ribeiro JG, Numata I et al. Ten- Year Landsat classification of deforestation and forest degradation in the Brazilian Amazon. Remote Sensing 2013; 5(11): 5493-5513. http:// dx.doi.org/10.3390/rs5115493.

Tritsch I, Arvor D. Transition in environmental governance in the Brazilian Amazon: emergence of a new pattern of socio-economic development and deforestation. Land Use Policy 2016; 59: 446-455. http://dx.doi.org/10.1016/j. landusepol.2016.09.018.

Uhl C, Kauffman JB. Deforestation, fire susceptibility, and potential tree responses to fire in the eastern Amazon. Ecology 1990; 71(2): 437-449. http://dx.doi. org/10.2307/1940299.

Veríssimo A, Cochrane CM. Concessions: catching a tiger by its tail? Tropical Forest 2003; 13(3): 1-6.

Weinhold D, Reis EJ, Vale PM. Boom-bust patterns in the Brazilian Amazon. Global Environmental Change 2015; 35: 391-399. http://dx.doi.org/10.1016/j.gloenvcha.2015.09.013.

West TPA, Vidal E, Putz FE. Forest biomass recovery after conventional and reduced-impact logging in Amazonian Brazil. Forest Ecology and Management 2014; 314: 59-63. http://dx.doi.org/10.1016/j.foreco.2013.11.022 